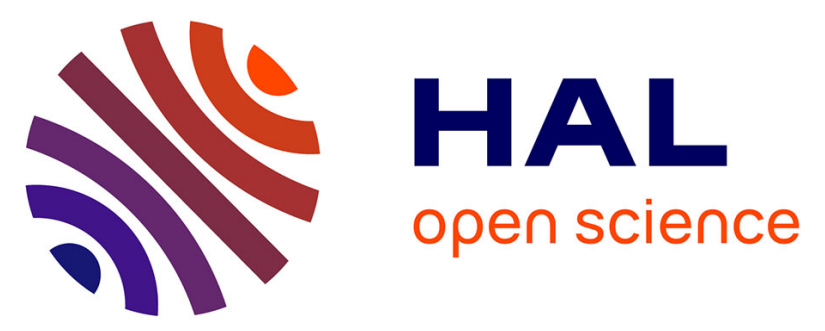

\title{
Characterisation by PIXE method of trace elements during physico-chemical reactions at the periphery of bioactive glass pastilles in contact with biological fluids
}

\author{
Edouard Jallot, P. Moretto
}

\section{- To cite this version:}

Edouard Jallot, P. Moretto. Characterisation by PIXE method of trace elements during physicochemical reactions at the periphery of bioactive glass pastilles in contact with biological fluids. 5th International Symposium on Trace Elements in human: New Perspectives, Oct 2005, Athens, Greece. pp.405-416, 10.1080/10739140600648803 . in2p3-00025081

HAL Id: in2p3-00025081

https://hal.in2p3.fr/in2p3-00025081

Submitted on 18 Nov 2005

HAL is a multi-disciplinary open access archive for the deposit and dissemination of scientific research documents, whether they are published or not. The documents may come from teaching and research institutions in France or abroad, or from public or private research centers.
L'archive ouverte pluridisciplinaire HAL, est destinée au dépôt et à la diffusion de documents scientifiques de niveau recherche, publiés ou non, émanant des établissements d'enseignement et de recherche français ou étrangers, des laboratoires publics ou privés. 


\section{Characterisation by PIXE method of trace elements during}

physico-chemical reactions at the periphery of bioactive glass pastilles in contact with biological fluids.

E. JALLOT ${ }^{1 *}$, Ph. MORETTO ${ }^{2}$

${ }^{1}$ Laboratoire de Physique Corpusculaire de Clermont-Ferrand CNRS/IN2P3 UMR 6533

Université Blaise Pascal - 24 avenue des Landais, 63177 Aubiere Cedex, France

${ }^{2}$ Centre d'Etudes Nucléaires de Bordeaux Gradignan CNRS/IN2P3 UMR 5797

Chemin du Solarium, Le Haut-Vigneau, BP 120, 33175 Gradignan Cedex

Keywords: PIXE - RBS - Bioactive glass - Bioactivity - Biomaterials - Dissolution - Apatite

* Corresponding author :

Edouard JALLOT

Laboratoire de Physique Corpusculaire de Clermont-Ferrand CNRS/IN2P3 UMR 6533

Université Blaise Pascal - 24 avenue des Landais, 63177 Aubière Cedex, France.

Tel : $33(0) 473407265$

Fax : 33 (0)4 73264598

E-mail : jallot@clermont.in2p3.fr 


\begin{abstract}
The prerequisite for bioactive glasses to bond to living bone is the formation of biologically active apatites on their surface in the body. Reactions and bioactivity mechanisms between bioactive glasses and bone depend on the glass composition. We study a glass in the $\mathrm{SiO}_{2}$ $\mathrm{Na}_{2} \mathrm{O}-\mathrm{CaO}-\mathrm{P}_{2} \mathrm{O}_{5}-\mathrm{K}_{2} \mathrm{O}-\mathrm{Al}_{2} \mathrm{O}_{3}-\mathrm{MgO}$ system. To characterise physico-chemical reactions at the materials periphery, we immersed the glass pastilles into biological fluids for delays of 5,10 and 20 days. The surface changes were studied at the micrometer scale by Particles Induced X-ray Emission (PIXE) method associated to Rutherford Backscattering Spectroscopy (RBS). After 20 days of immersion, elemental maps showed the formation of a calcium-phosphate layer at the surface of the glass pastilles. The thickness of this layer was around $15 \mu \mathrm{m}$. Thanks to PIXE method, we demonstrated the presence of traces of $\mathrm{Mg}$ in this layer. The glass doped with $\mathrm{MgO}$ leads to the formation of an apatite which incorporates magnesium. Formation of this Ca-P-Mg layer represents the bioactive properties of the studied glass. This biologically active layer improves the properties of the glass and will permit a chemical bond between the ceramic and bone.
\end{abstract}




\section{Introduction}

Integration of an implant into bone is crucial to success; thus the establishment of an enduring interface between the implant and bone is very important. Bioactive glasses and glass-ceramics are able to bond to bone in vivo through the formation of an apatite surface layer ${ }^{[1-4]}$. This property has become known as bioactivity. Hench L.L. demonstrated this bioactive properties for certain glass composition ${ }^{[1,5]}$. Dynamic ion exchange and bonding to bone were demonstrated for a certain compositional range with $\mathrm{SiO}_{2}, \mathrm{Na}_{2} \mathrm{O}, \mathrm{CaO}$ and $\mathrm{P}_{2} \mathrm{O}_{5}$ in specific proportions $^{[6,7]}$.

Bioactive glasses can be proposed both as bulk and coating for several kind of applications, especially focused on orthopaedics, where load bearing is required ${ }^{[8]}$. Several bioactive glasses can be used to prepare biocomposites, most of them belonging to the system $\mathrm{SiO}_{2}-\mathrm{CaO}-\mathrm{Na}_{2} \mathrm{O}-\mathrm{P}_{2} \mathrm{O}_{5}$ with different amounts of other oxides $\left(\mathrm{B}_{2} \mathrm{O}_{3}, \mathrm{Al}_{2} \mathrm{O}_{3}, \mathrm{MgO}, \mathrm{Zr}_{2} \mathrm{O}\right.$ etc ...) which provided different properties in terms of surface reactivity ${ }^{[9]}$. The following paper concerns a bioactive glass in the $\mathrm{SiO}_{2}-\mathrm{Na}_{2} \mathrm{O}-\mathrm{CaO}-\mathrm{P}_{2} \mathrm{O}_{5}-\mathrm{K}_{2} \mathrm{O}-\mathrm{Al}_{2} \mathrm{O}_{3}-\mathrm{MgO}$ system. Critical concentrations of magnesium can play an important role during physicochemical reactions at the material periphery. On the other hand, aluminium may inhibits apatite precipitation or reduces glass matrix dissolution ${ }^{[10]}$. Together with the development of glasses, several efforts have been pursued in order to explain the mechanism responsible for their in vitro and in vivo behaviours ${ }^{[7,11]}$. However, the formation of the apatite layer is not explained in detail because of the complexity of events occurring at the interface and the specific role of trace elements. Most of authors focussed their investigations on $\mathrm{Si}, \mathrm{Ca}, \mathrm{P}$ but others elements and specially trace elements like Mg might play an important role during physico-chemical reactions.

The purpose of the present paper is to characterize physico-chemical reactions at the glass periphery during interactions with biological fluids and to evaluate the role of major and trace elements in bioactivity mechanisms. We study a glass in the $\mathrm{SiO}_{2}-\mathrm{Na}_{2} \mathrm{O}-\mathrm{CaO}-\mathrm{P}_{2} \mathrm{O}_{5}-$ 
$\mathrm{K}_{2} \mathrm{O}-\mathrm{Al}_{2} \mathrm{O}_{3}-\mathrm{MgO}$ system. Physico-chemical reactions and bioactive properties of the glass doped with $\mathrm{MgO}$ are studied during interactions between glass pellets and biological fluids. Knowledge of the elemental distribution at the bioactive glass periphery is important to understand the physico-chemical mechanisms during interactions with biological fluids. Chemical evaluation of the glass/biological fluids interface was performed by Particles Induced X-ray Emission (PIXE) associated to Rutherford Backscattering Spectroscopy (RBS). These two methods are especially suitable for the study of this kind of interaction under the micrometer scale and permit elemental maps of interfaces ${ }^{[12,13]}$. Moreover, PIXE method permits the detection of trace elements $(\mu \mathrm{g} / \mathrm{g})$ that was not possible by Energy Dispersive X-ray Spectroscopy (EDXS).

\section{Materials and Methods}

\section{Bioactive glass pastilles characteristics}

The bioactive glass composition is : $50 \% \mathrm{SiO}_{2}, 20 \% \mathrm{Na}_{2} \mathrm{O}, 16 \% \mathrm{CaO}, 6 \% \mathrm{P}_{2} \mathrm{O}_{5}, 5 \%$ $\mathrm{K}_{2} \mathrm{O}, 2 \% \mathrm{Al}_{2} \mathrm{O}_{3}$ and $1 \% \mathrm{MgO}$ (\% weight). The bioactive glass was obtained by melting a mixture of raw materials in a platinum crucible at high temperature $\left(2\right.$ hours at $1200^{\circ} \mathrm{C}$ and 3 hours at $1350^{\circ} \mathrm{C}$ ). The mixture of raw materials contained : sand Sibelco, aluminium oxide, anhydrous dibasic sodium phosphate, calcium carbonate, potassium carbonate, basic magnesium carbonate. Then, the glass was cast, crushed and transformed into powder of grain size under $40 \mu \mathrm{m}$ in diameter. After production, the glass composition was determined by Atomic Emission Spectrometry. Finally, pastilles (13 $\mathrm{mm}$ in diameter and $1 \mathrm{~mm}$ in thickness) were obtained under pressure with the glass powder. 


\section{Sample treatment and Specimens preparation}

The glass pastilles were immersed at $37^{\circ} \mathrm{C}$ for 5,10 and 20 days in $45 \mathrm{ml}$ of a standard Dulbecco's Modified Eagle Medium (DMEM, VWR International S.A.S., France) (pH : 7.3). DMEM contained the following ingredients (mg/l): $6400 \mathrm{NaCl}, 400 \mathrm{KCl}, 200 \mathrm{CaCl}_{2}, 200$ $\mathrm{MgSO}_{4}-7 \mathrm{H}_{2} \mathrm{O}, 124 \mathrm{NaH}_{2} \mathrm{PO}_{4}, 3700 \mathrm{NaHCO}_{3}$.

After treatment the glass pellet was lying on the bottom of the box. The medium was carefully removed and the glass pellet was embedded in resin (AGAR, Essex, England). Thin sections of $20 \mu \mathrm{m}$ nominal thickness are prepared by means of a Leica RM 2145 microtome. Cutting is made perpendicular to the surface of glass pastilles. Then, the sections are placed on a mylar film with a hole of $3 \mathrm{~mm}$ in the centre. Measurements are performed on the area of the section placed over the hole.

\section{Ion beam methods (PIXE-RBS) of analysis}

Particles Induced X-ray Emission (PIXE) and Rutherford Backscattering Spectroscopy (RBS) are used simultaneously. PIXE method permits to identify and, when possible, to quantify trace elements. RBS method is used to determine the quantity of electric charge received by the sample during irradiation which is essential for quantification of PIXE spectra.

RBS measurements were done with a silicon particle detector placed at $135^{\circ}$ from incident beam axis. Its surface was $20 \mathrm{~mm}^{2}$. The detector was used to monitor the total number of protons that interacted with the target during analysis via the yield of backscattered particles. Data were treated using SIMNRA code developed at the Max-Planck-Institut fur PlasmaPhysik (Garching, Germany) ${ }^{[14]}$.

PIXE analysis was performed with an $\mathrm{Si}(\mathrm{Li})$ semiconductor detector placed at $135^{\circ}$ from the incident ion beam axis. The surface of the crystal was $80 \mathrm{~mm}^{2}$ and its thickness was 
$3 \mathrm{~mm}$. This detector was fitted with a beryllium window $12 \mu \mathrm{m}$ in thickness. No filter was used for our analyses. To analyse spectra obtained by PIXE we used GuPIX software developed at Guelph University, Canada ${ }^{[15]}$. This package provides a non-linear least-square method to fit spectra, together with conversions of X-ray peak intensities to elemental concentrations via a defined standardization technique involving solid angle of detection, relative charge and user-defined instrument constants. In our case, concentrations are expressed in $\mu \mathrm{g} / \mathrm{g}$ of resin-embedded material.

Analytical measurements were performed using nuclear microprobes at the Centre d'Etudes Nucléaires de Bordeaux-Gradignan (CENBG) (Bordeaux, France). This facility is based on a microbeam line that is used to carry out ion beam analytical techniques at the micrometer scale ${ }^{[16]}$. For these measurements we employed proton microbeams of $1.5 \mathrm{MeV}$ in energy and $100 \mathrm{pA}$ in intensity. The beam diameter was near $2 \mu \mathrm{m}$. In order to realise multielemental maps of glass pastilles/biological fluids interface, we adjusted the scanning system with a $50 \mathrm{~Hz}$ frequency. A proton beam of energy $1.5 \mathrm{MeV}$ gives a good ionization crosssection of light elements $(Z<20)$ and thus a better sensitivity for PIXE analysis by using a $\mathrm{Si}(\mathrm{Li})$ detector without filter. The scanning rate, weak intensity and the choice of protons as ion beam allow the target degradation to be minimized during irradiation. The beam intensity is not too weak and thus permits acquisition duration of 1 hour.

\section{Results}

Concentrations gradients of $\mathrm{Si}, \mathrm{Ca}, \mathrm{P}, \mathrm{Al}$ and $\mathrm{Mg}$ across the periphery of bioactive glass pastilles were studied by proton beam microanalysis on thin sections. Elemental mappings for different exposure times to biological solution revealed different zones from the centre to the surface of the bioactive glass pastilles (figures 1,2 ). 

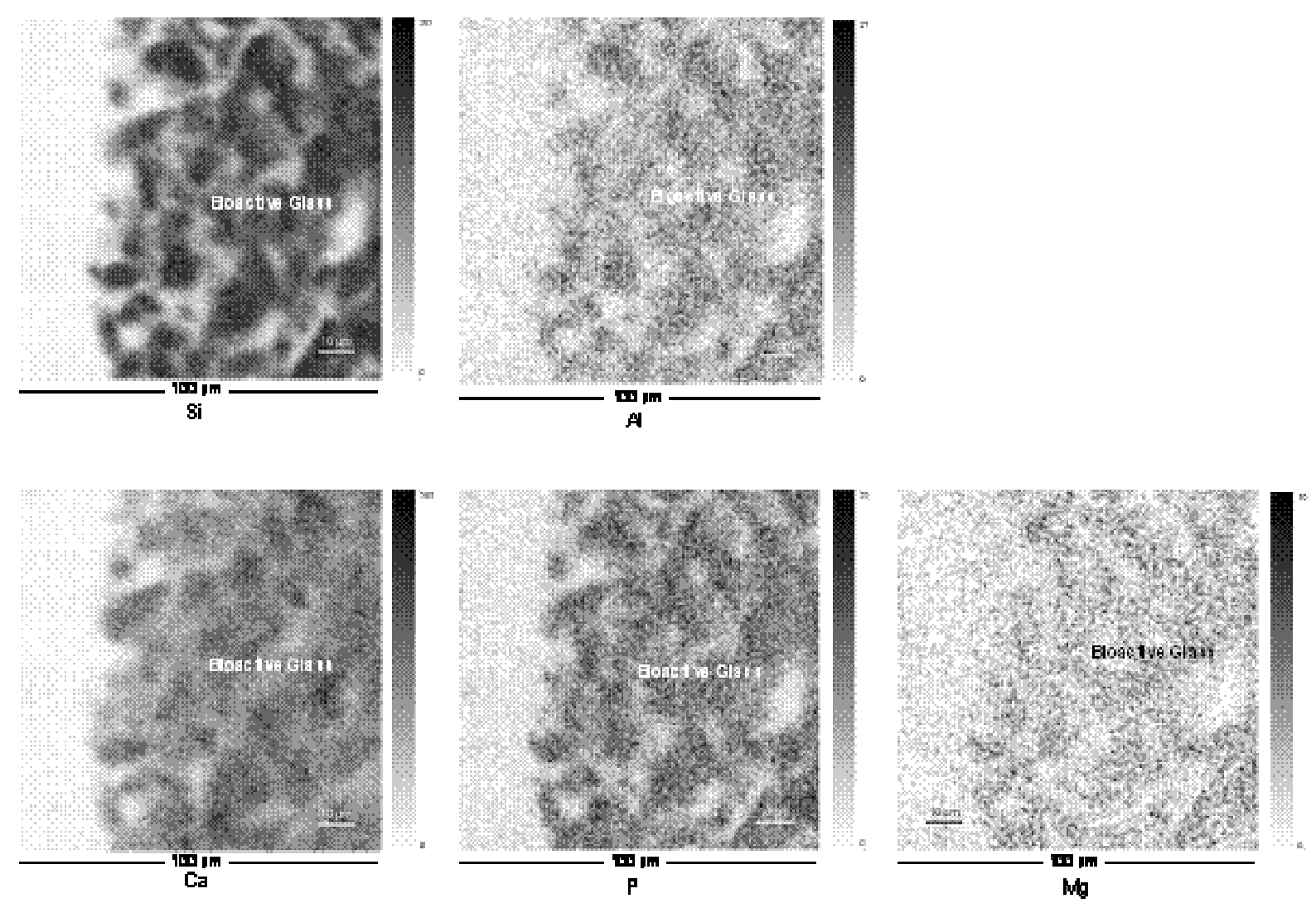

Figure 1: $\mathrm{Si}, \mathrm{Al}, \mathrm{Ca}, \mathrm{P}$ and $\mathrm{Mg}$ maps at the bioactive glass pellets periphery before immersion in biological fluids.

Before immersion into biological fluids, the bioactive glass pastille periphery is homogeneous (figure 1). Concentrations of $\mathrm{Si}, \mathrm{Ca}, \mathrm{P}, \mathrm{Al}$ and $\mathrm{Mg}$ are constant (figure 1, table 1). After 5 and 10 days of immersion into biological fluids, we observed the same homogeneous periphery. However, we found a decrease in $\mathrm{Si}, \mathrm{Ca}, \mathrm{P}$ and $\mathrm{Mg}$ concentrations in the bioactive glass pastille periphery (table 1). On the other hand, $\mathrm{Al}$ concentrations increase. 


\begin{tabular}{cccccc}
\hline & Si & Al & Ca & P & Mg \\
\hline Before immersion & $248411 \pm 9087$ & $9831 \pm 376$ & $135160 \pm 13094$ & $35890 \pm 1730$ & $5245 \pm 674$ \\
$\begin{array}{c}5 \text { days after } \\
\text { immersion }\end{array}$ & $245858 \pm 7623$ & $10060 \pm 497$ & $134156 \pm 6148$ & $34337 \pm 1170$ & $5168 \pm 373$ \\
$\begin{array}{c}\text { 10 days after } \\
\text { immersion }\end{array}$ & $232567 \pm 3459$ & $10860 \pm 283$ & $133562 \pm 11134$ & $32337 \pm 1445$ & $5031 \pm 171$ \\
$\begin{array}{c}\text { 20 days after } \\
\text { immersion }\end{array}$ & $221156 \pm 18143$ & $11789 \pm 338$ & $120035 \pm 15061$ & $27553 \pm 706$ & $4061 \pm 453$ \\
\hline
\end{tabular}

Table 1: Elemental concentrations ( $\mu \mathrm{g} / \mathrm{g}$ of resin embedded-material) of $\mathrm{Si}, \mathrm{Al}, \mathrm{Ca}, \mathrm{P}, \mathrm{Mg}$ in the glass before immersion in DMEM and after 5, 10 and 20 days of immersion in DMEM.

After 20 days of immersion into biological fluids, we observe two areas at the bioactive glass pastille surface (figure 2). The first area is composed with $\mathrm{Si}, \mathrm{Ca}, \mathrm{P}, \mathrm{Al}, \mathrm{Mg}$ and represents the glass. The second area is essentially composed with $\mathrm{Ca}, \mathrm{P}$ together with traces of $\mathrm{Mg}$. At this time period, a Ca-P-Mg layer appears at the surface of bioactive glass pastilles. The thickness of this layer is in the order of $15 \mu \mathrm{m} . \mathrm{Ca}, \mathrm{P}, \mathrm{Si}$ and $\mathrm{Mg}$ concentrations in the bioactive glass continue to decrease and $\mathrm{Al}$ concentration increases (table 1). High $\mathrm{Ca}$, $\mathrm{P}$ concentrations are found in the layer together with a low concentration of $\mathrm{Mg}$ (table 2). The $\mathrm{Ca} / \mathrm{P}$ atomic ratio in this layer is near 1.7 .

\begin{tabular}{cccccc}
\hline & Si & Al & Ca & P & Mg \\
\hline $\begin{array}{c}20 \text { days after } \\
\text { immersion }\end{array}$ & $21447 \pm 871$ & $1235 \pm 382$ & $389047 \pm 38961$ & $180055 \pm 5421$ & $10275 \pm 1652$ \\
\hline
\end{tabular}

Table 2: Elemental concentrations ( $\mu \mathrm{g} / \mathrm{g}$ of resin embedded-material) of $\mathrm{Si}, \mathrm{Al}, \mathrm{Ca}, \mathrm{P}, \mathrm{Mg}$ in the surface layer after 20 days of immersion in DMEM. 



Figure 2: $\mathrm{Si}, \mathrm{Al}, \mathrm{Ca}, \mathrm{P}$ and $\mathrm{Mg}$ maps at the bioactive glass pellets periphery after 20 days of immersion in biological fluids.

\section{Discussion}

The present work analyzes the surface changes of glass pastilles in the $\mathrm{SiO}_{2}-\mathrm{Na}_{2} \mathrm{O}-$ CaO- $\mathrm{P}_{2} \mathrm{O}_{5}-\mathrm{K}_{2} \mathrm{O}-\mathrm{Al}_{2} \mathrm{O}_{3}-\mathrm{MgO}$ system and immersed into biological fluid. To understand mechanisms of interaction between glass and biological fluids a physico-chemical approach is adopted, namely the analysis of the transformation kinetics of the pastilles periphery by means of PIXE-RBS. PIXE associated to RBS permits to obtain quantitative chemical mappings of all elements with a $\mathrm{Z}>11(\mathrm{Na})$ at the micrometer scale. Thanks to PIXE method we can study major, minor and even trace elements with concentrations of some $\mu \mathrm{g} / \mathrm{g}$. In this study we focused our attention on $\mathrm{Si}, \mathrm{Al}, \mathrm{Ca}, \mathrm{P}, \mathrm{Mg}$ elements and we do not discuss behaviour 
of $\mathrm{Na}$ and $\mathrm{K}$ because these elements are not firmly bond in the glass matrix and rapidly released. Analysis of diffusible elements like $\mathrm{Na}$ and $\mathrm{K}$ is interesting but it is impossible to do this study on bulk samples embedded in resin. It would be better to study these elements on glass particles and by using cryo-methods associated to electron probe microanalysis ${ }^{[4,17-19]}$. Chemical mappings across the periphery of glass pastilles show the physico-chemical reactions occurring at the surface of the glass in contact with biological fluids.

During interactions between the bioactive glass pastilles and biological fluids several physico-chemical reactions occur at the material surface. The bioactive composition evolves with time of immersion into biological fluids. $\mathrm{Si}, \mathrm{Ca}, \mathrm{P}$ and $\mathrm{Mg}$ concentrations in the glass decrease with time. These elements are released into the solution and the glass undergoes dissolution (figure 3). Aluminium concentration increases in the glass because this element is not released like other elements. $\mathrm{Al}^{3+}$ ions are lower released than other ions because it is firmly bonded to $\mathrm{Si}$. During the bioactive glass dissolution, $\mathrm{Al}_{2} \mathrm{O}_{3}$ is bonded to the unreleased part of silicon. $\mathrm{Al}_{2} \mathrm{O}_{3}$ is a network former and its addition in bioactive glasses can be used to control and reduce the solubility of the glass ${ }^{[10,11]}$.

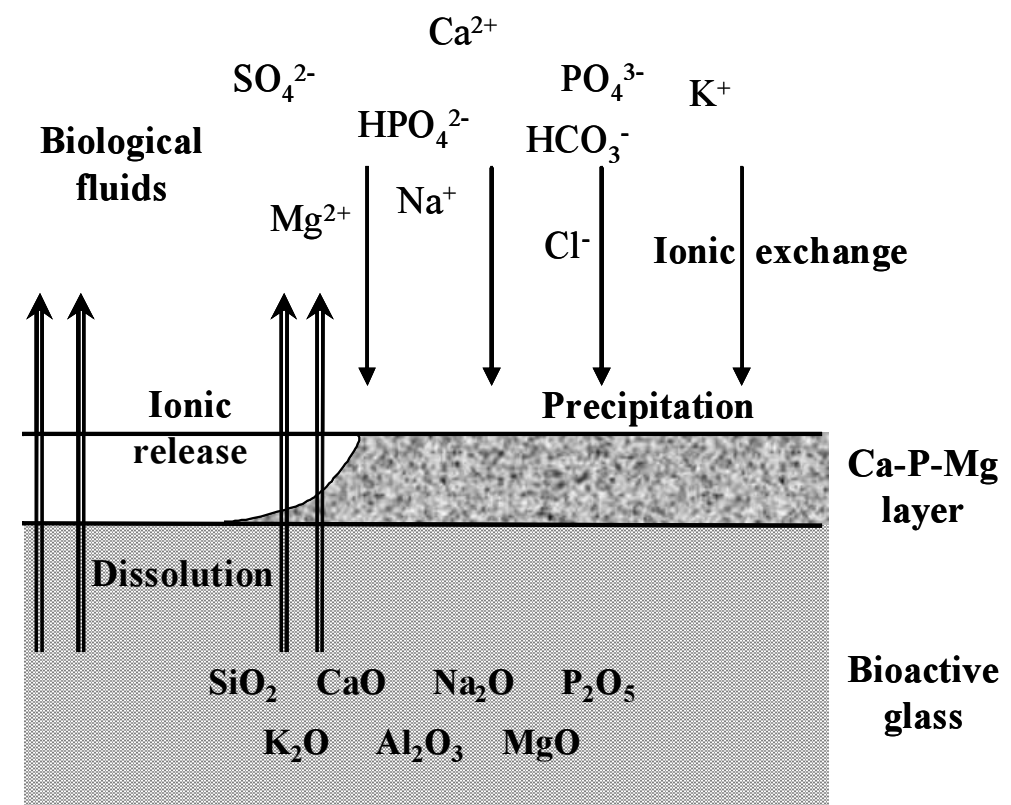


Figure 3 : Schematic view of the Ca-P-Mg surface layer and physico-chemical reactions at the bioactive glass periphery after 20 days of exposure to biological fluids.

As the glass matrix dissolves, various elements dispersed in the bioactive glass are free to go either into the solution or to combine with elements in the bioactive glass that make up surface layers. After 20 days of immersion into biological fluids, the distribution of silicon, aluminium, calcium, phosphorus and magnesium differs between the glass pastilles centre and the surface. Concentration gradients demonstrate the formation of a $\mathrm{Ca}-\mathrm{P}$ rich layer which contains $\mathrm{Mg}$. Formation of this layer includes a complex series of physico-chemical and ultrastructural phenomena. Bioactive glass pastilles in contact with biological fluids are in dissolution and $\mathrm{Si}, \mathrm{Ca}, \mathrm{P}, \mathrm{Na}, \mathrm{K}, \mathrm{Mg}$ are released. $\mathrm{Na}^{+}$and $\mathrm{K}^{+}$ions are rapidly and highly released $^{[17]}$. An appreciable amount of $\mathrm{Si}, \mathrm{Ca}, \mathrm{P}, \mathrm{Mg}$ ions is released from the bioactive glass into the surrounding fluids. The dissolution results from breaking of Si-O-Si bonds and leads to the formation of a new materials composed with $\mathrm{Si}, \mathrm{Al}, \mathrm{Ca}, \mathrm{P}$ and $\mathrm{Mg}$. Then, an accumulation of $\mathrm{Ca}^{2+}, \mathrm{PO}_{4}{ }^{3-}$ ions occurs on top of this material and a Ca-P rich layer start to build up. This Ca-P layer evolves with time of exposure to biological solution. The size of this layer increases and after 20 days is near $15 \mu \mathrm{m}$. The $\mathrm{Ca} / \mathrm{P}$ atomic ratio in the calcium phosphate layer increases to 1.7 after this time period of immersion which corresponds to the atomic ratio of an apatite.

These reactions reflect the formation of an apatite layer at the bioactive glass surface. Formation and growth of the amorphous Ca-P rich film is by incorporation of soluble calcium and phosphates ions coming both from the glass and the solution (figure 3 ). $\mathrm{Ca}^{2+}$ ions increase the degree of supersaturation of the surrounding biological fluids and cause precipitation. These specifics precipitation conditions lead to the formation of bone apatite like crystals. Formation of this apatite layer represents bioactivity properties of bioactive glasses. Evolution of this dynamic interface and the formation of the apatite layer will permit in vivo a chemical 
bond between the bioactive glass and bone tissues. Thus, a bioactive interfacial region is formed.

In the case of bioactive glasses doped with $1 \%$ of $\mathrm{MgO}$, the apatite layer contains magnesium. The presence of $\mathrm{Mg}$ does not inhibit bioactivity. But, the precipitation conditions favour the formation of apatite-like crystals, which incorporate magnesium. This kind of biologically relevant calcium phosphate is important for bone bonding ${ }^{[20]}$. $\mathrm{Mg}$ can play an important role during spontaneous formation of in vivo calcium phosphates and bone bonding ${ }^{[21]} . \mathrm{Mg}^{2+}$ incorporated into the apatite lattice can induce changes in its physicochemical properties. Apatite substituted with $\mathrm{Mg}$ results in a $\mathrm{Ca}$ deficient apatite which is more soluble than stoichiometric apatite ${ }^{[21]}$.

\section{Conclusion}

In case of bioactive glasses that undergo dissolution due to ion diffusion, spatially resolved X-ray microanalyses is of great importance in evaluating mechanisms of physicochemical reactions between material and biological fluids, because the phenomenon occurs under micrometer scale. Thanks to PIXE method we are able to study major, minor and trace elements at the required scale. Physico-chemical reactions can be decomposed in ion leaching, partial dissolution of the glass-surface which lead to the formation of a bone like apatite layer on the glass surface. Formation of the apatite layer represents bioactivity properties of the studied bioactive glass. Presence of $2 \% \mathrm{Al}_{2} \mathrm{O}_{3}$ in the bioactive glass reduces its dissolution but do not inhibit its bioactivity.

The prerequisite for bioactive glasses to bond to living bone is the formation of biologically active apatites on their surface in the body. The apatite layer bridges chemically the bone and the implant. The reactions between bioactive glasses and bone, and dependence of these reactions on the glass composition are important in bioactivity mechanisms. Our 
results demonstrate this property of bioactivity for the studied bioactive glass. The bioactive glass in the $\mathrm{SiO}_{2}-\mathrm{Na}_{2} \mathrm{O}-\mathrm{CaO}-\mathrm{P}_{2} \mathrm{O}_{5}-\mathrm{K}_{2} \mathrm{O}-\mathrm{Al}_{2} \mathrm{O}_{3}-\mathrm{MgO}$ system leads to the formation of a Ca-P$\mathrm{Mg}$ rich layer. This paper demonstrates the presence of $\mathrm{Mg}$ in the $\mathrm{Ca}-\mathrm{P}$ rich layer at the interface between the bioactive glass and biological fluids. However, magnesium influences the formation and the evolution of the apatite layer. The Mg may be able to enter the forming hydroxyapatite nuclei and thus inhibits their evolution to tiny apatite crystals, because this element can not be accommodated in the hydroxyapatite structure.

\section{References}

1. Hench, L.L.; Splinter, R.J.; Greenlee, T.K.; Allen, W.C. Bonding mechanism at the interface of ceramic prosthetic materials. J. Biomed. Mater. Res. 1971, 5, 117.

2. Kitsugi, T.; Yamamuro, T.; Nakamura, T.; Higashi, S.; Kakutani, Y.; Hyakuna, K.; Ito, S.; Kokubo, T.; Takagi, M.; Shibuya, T. Bone bonding behaviour of three kinds of apatite containing glass ceramics. J. Biomed. Mater. Res. 1986, 20, 1295.

3. Ohtsuki, C.; Kokubo, T.; Yamamuro, T. Mechanism of apatite formation on $\mathrm{CaO}-\mathrm{SiO}_{2}-$ $\mathrm{P}_{2} \mathrm{O}_{5}$ glasses in simulated body fluid. J. Non-cryst. Solids 1992, 143, 84.

4. Jallot, E. ; Benhayoune, H. ; Kilian, L. ; Josset, Y. ; Balossier, G. An original method to assess short-term physico-chemical reactions at the periphery of bioactive glass particles into biological fluids. Langmuir 2001, 17, 4467.

5. Neo, M.; Nakamura, T.; Kikutani, T.; Kawanabe, K.; Kokubo T. Apatite formation on three kinds of bioactive material at an early stage in vivo:Acomparative study by transmission electron microscopy. J. of Biomed. Mater. Res. 1993, 27, 999.

6. Ohtsuki, C.; Kokubo, T.; Yamamuro, T. Mechanism of apatite formation on $\mathrm{CaO}-\mathrm{SiO}_{2}-$ $\mathrm{P}_{2} \mathrm{O}_{5}$ glasses in simulated body fluid. J. Non-cryst. Solids 1992, 143, 84. 
7. Hench, L.L. Bioceramics: from concept to clinic. J. Am. Ceram. Soc. 1991, 74, 1487.

8. Oliva, A.; Salerno, A.; Locardi, B.; Riccio, V.; Della Ragione, F.; Iardino, P.; Zappia, V. Behavior of human osteoblasts cultured on bioactive glass coatings. Biomaterials 1998, 19, 1019.

9. Kokubo, T.; Kushitani, H.; Ohtsuki, C.; Sakka, S.; Yamamuro, T. Chemical reaction of bioactive glass and glass-ceramics with a simulated body fluid. J Mater. Sci. Mat. Med. 1992, 3,79 .

10. Greenspan, D.C.; Hench, L.L. Chemical and mechanical behavior of bioglass-coated alumina. J. Biomed. Mater. Res. 1976, 10, 503.

11. Jallot, E.; Benhayoune, H.; Kilian, L.; Irigaray, J.L.; Barbotteau, Y.; Balossier, G.; Bonhomme, P. Dissolution kinetics, selective leaching and interfacial reactions of a bioglass coating enriched in alumina. J. Colloid Interface Sc. 2001, 233, 83.

12. Jallot, E.; Irigaray, J.L.; Weber, G.; Frayssinet, P. In vivo characterisation of the interface between cortical bone and biphasic calcium phosphate by P.I.X.E. method. Surf. Interface Anal. 1999, 27, 648 .

13. Jallot, E.; Benhayoune, H.; Weber, G.; Balossier, G.; Bonhomme, P. Characterization of the interface between hydroxyapatite coating film and bone: Use of a new expression to correct matrix effects for PIXE measurements in thick samples embedded in resin. Journal of Physics D : Applied Physics 2000, 33 (4), 321.

14. Mayer, M. SIMNRA User's guide, Report IPP 9/113. Max-Planck-Institut fur Plasmaphysik, Garching, Germany 1997.

15. Maxwell, J.A.; Teesdale, W.J.; Campbell, J.L. The Guelph PIXE software package II. Nucl. Instrum. Methods 1995, B95, 407.

16. Llabador, Y.; Moretto, Ph.; Guegan, H. Light-element analysis with the CENBG nuclear microprobe. Nucl. Instrum. Methods 1993, B77, 123. 
17. Jallot, E.; Benhayoune, H.; Kilian, L.; Josset, Y.; Kinetics of short-term physico-chemical reactions at the periphery of bioactive glass particles. A TEM cryo-X-ray microanalysis of diffusible ions. Langmuir 2003, 19, 3840.

18. Zierold, K. Cryofixation methods for ion localization in cells by electron probe microanalysis. J. Microscopy 1991, 161, 357.

19. Roomans, G.M. Quantitative X-ray microanalysis of biological specimens. J. Electron. Microsc. Tech. 1988, 9-1, 19.

20. Kybalczyc, W.; Christoffersen, J.; Christoffersen, M.R.; Zielenkiewicz, A.; Zielenkiewicz, W. J. Cryst. Growth 1990, 106, 355.

21. Legeros, R.Z.; Kijkowska, R.; Kattech, I.; Jemal, M.; Legeros, J.P. J. Dent. Res. 1986, 65, 783. 